\title{
Validity Evidence of the Z-Test-SC for Use With Children ${ }^{1}$
}

\author{
Anna Elisa de Villemor-Amaral ${ }^{2}$ \\ Universidade São Francisco, \\ Itatiba-SP, Brazil
}

\author{
Pâmela Malio Pardini Pavan \\ Universidade São Francisco, \\ Itatiba-SP, Brazil
}

\author{
Raquel Rossi Tavella \\ Centro Universitário Nossa Senhora \\ do Patrocínio, Itu-SP, Brazil
}

\author{
Lucila Moraes Cardoso \\ Universidade Estadual do Ceará, \\ Fortaleza-CE, Brazil
}

\author{
Fabiola Cristina Biasi \\ Universidade São Francisco, \\ Itatiba-SP, Brazil
}

\begin{abstract}
In Brazil, there is a lack of tools to assess the children's affective and cognitive dynamics and investments are needed in research that seeks evidence of validity of some assessment tools for that public. The Zulliger test in the Comprehensive System (Zulliger-SC) evaluates the adequacy of reality perception, affects, self-perception, interpersonal relationship and cognitive processing and can be used with children, although there are few studies with this purpose in Brazil. Thus, the aim was to contribute in this field, comparing the performances in different stages of development. The participants were 103 children aged 6 and 12 years old, students from public schools in the state of São Paulo, who answered the test individually in the schools. The Zulliger-SC distinguished the children consistently with what is theoretically expected for their age, bringing some evidence of the Zulliger's validity with children.
\end{abstract}

Keywords: Zulliger Z test, test validity, childhood development

\section{Evidências de Validade do Zulliger-SC Para Uso com Crianças}

\begin{abstract}
Resumo: No Brasil, há uma escassez de instrumentos para avaliar a dinâmica afetiva e cognitiva de crianças, sendo necessário investir em pesquisas que busquem evidências de validade de técnicas de avaliação para esse público. O Teste de Zulliger no Sistema Compreensivo (Zulliger-SC) é um instrumento que avalia o modo de apreensão da realidade, afetos, auto-percepção, relacionamento interpessoal e funcionamento cognitivo, sendo indicado para uso com crianças, embora sejam escassos os estudos que demonstrem sua validade. Buscou-se contribuir para preencher essa lacuna, comparando os desempenhos de crianças em diferentes etapas do desenvolvimento. Participaram da pesquisa 103 crianças de 6 e 12 anos, estudantes de escolas públicas do interior do estado de São Paulo, que responderam ao instrumento individualmente, na própria escola. O Zulliger-SC diferenciou os participantes de modo coerente ao esperado teoricamente para suas idades, contribuindo com evidências de validade de uso do Zulliger-SC com crianças.
\end{abstract}

Palavras-chave: teste de Zulliger, validade do teste, desenvolvimento infantil

\section{Evidencia de Validez de la Prueba Zulliger-SC Para Uso con los Niños}

\begin{abstract}
Resumen: En Brasil, hay relativa falta de herramientas para evaluar la dinámica afectiva y cognitiva de niños, siendo necesario invertir en investigaciones que buscan evidencias de validez de algunas técnicas para esa población. El Zulliger - Sistema Integrado (Zulliger-SI) es un instrumento que evalúa el modo de percibir la realidad, los afectos, la autopercepción, la relación interpersonal y funcionamiento cognitivo y puede ser utilizado con niños, pero hay pocos estudios con ese propósito en Brasil. Por lo tanto, el objetivo fue contribuir en este campo, comparándose las respuestas de niños con distintas edades. Participaran 103 niños de 6 e 12 años, estudiantes de escuelas públicas en el estado de São Paulo, que respondieron al test individualmente en la propia escuela. El Zulliger-SC ha diferenciado los niños consistentemente a lo esperado teóricamente para las edades, contribuyendo para validez de su uso con niños.
\end{abstract}

Palabras clave: test de Zulliger, validación de test, desarrollo infantil

Childhood is marked by different development phases with distinct characteristics, demanding refined resources from psychologists to assessing the cognitive and emotional aspects relatively expected for each phase, which permits an appropriate investigation of the child's potentials

\footnotetext{
${ }^{1}$ Support: National Council for Scientific and Technological Development CNPq (Grant \# 475633/2006-7).

${ }^{2}$ Correspondence address:

Anna Elisa de Villemor-Amaral. Universidade São Francisco. Rua Alexandre Rodrigues Barbosa, 45, Centro. CEP 13251-900. Itatiba-SP, Brazil. E-mail: anna.villemor@usf.edu.br
}

and limitations (Nascimento, Pedroso, \& Souza, 2009). According to Semer (2008), although the child's personality is being established, the use of psychological assessment tools permits a more appropriate understanding of their characteristics, considering the peculiarities of the different phases of childhood development.

Different theoreticians have studied childhood development, appointing different phases in cognitive and affective development. Among experts in the area, Piaget is mentioned, for example, who offered important understandings with his epistemological theory of human development. In this theory, the author explains that, in 
the course of their development, the children go through different cognitive stages that directly influence the way of relating with the world. In Piaget's epistemological theory (1978), cognitive development is marked by four stages that are characterized by a series of behaviors typical of each period. Therefore, it is very important for the psychologists to be able to count on methods that satisfactorily apprehend the characteristics of the phases the children being assessed go through, as these are in constant emotional, social and cognitive development (Nunes, Teixeira, \& Deakin, 2010).

Different authors have appointed the Rorschach Method as a highly useful instrument, as it permits the understanding of emotional, social and cognitive functioning (Fernandes, 2010; Hisatugo \& Custódio, 2013; Jacquemin, 2012; Nascimento et al., 2009; Raspantini, 2010; Resende, Carvalho, \& Martins, 2012; Ribeiro, Semer, \& Yazigi, 2011; Semer, 2008). Despite using different interpretative systems of the Rorschach, all of these studies have indicated possibilities to use the same method with children. According to Viglione (1999), for example, in the Rorschach, age is associated with the complexity of the answers, so that the evolution of development is evidenced in the increasingly complex answers the subjects provide.

Even if the interpretative meanings of the RorschachSC involve universally applicable descriptive aspects, the interpretative meaning of the indicators depends on normative standards. Hence, justifying the lack of normative standards to apply the Rorschach Method with children in Brazil, Ribeiro et al. (2011) intended to set standards for the use of the RorschachSC for male and female children between 7-10 from public and private schools, totaling 221 participants. The authors initially developed a consistency study between evaluators and the coefficient ranged between .65 and .97 , varying between average and excellent. Most variables obtained an agreement coefficient superior to .90 in practically all variables, except for the determinants and formal quality. The comparative analyses of the children from public and private schools revealed statistically significant differences in some variables, indicating that the children from private schools demonstrated greater facility to associate and produce answers, higher situational stress rates and better capacity to cope with complex affective situations and to intellectually manipulate the affection. These characteristics reveal that the children from more privileged social classes deal with complex situations more easily. They were also more anxious, perhaps because they felt greater pressure and because they have to spend time on different extracurricular activities, as reported by the children's parents. The children from public schools, on the other hand, presented a more formal attitude and less variable reactions, demonstrating less involvement and a more simplified perception. The results revealed that boys and girls tend to obtain similar results in the variables Rorschach Comprehensive System. Finally, the authors created the normative tables for the variables Rorschach Comprehensive System per age range between 7 and 10 years and according to the origin from public or private schools.

Resende et al. (2012) developed a similar study when they analyzed the performance on the Rorschach-SC method of 201 children and adolescents between 5 and 14 years of age, separated in three age groups. The participants were randomly selected based on public and private schools from nine regions in Goiânia-GO. Based on the inter-rater agreement analysis of $25 \%$ of the sample, it was observed that the agreement percentages varied between .89 and .99 and the Kappa coefficients between .78 and .98. The descriptive and inferential statistics of the Rorschach variables were also calculated. Among the results presented, it was verified that variables related to the coherent and precise processing of information, indicated by the good formal quality of the answers (FQ+ and FQo), the appropriate perception of more obvious situations in the global answers and simple details (WDo), the efficiency and complexity in information processing $(\mathrm{DQ}+)$ and availability for cooperative and welcoming attitudes (COP) obtained a high frequency as age advances. In addition, the variables WDA, WDA\%, DQ+, DQo, FQo, R, D, SumSh, the latter related to the presence of anxiety, were significantly increased in the higher age range (12-14 years), are in accordance with the earlier assertions. The authors concluded that, as the participants' age advances, the answers to the Rorschach gain complexity and precision, contributing to the assessment of children with different age ranges.

Another tool, with a structure very similar to the Rorschach and potential for use with children is the Zulliger Test. The Zulliger Test is an expressive method, like in the Rorschach, composed of unstructured stimuli aimed at producing information on the assessed person's personality. It was created by the psychologist Hans Zulliger, who needed to assess a large group of people and had to develop a simplification of the method to reduce the application time and analysis. Thus, he created new inkblots and concluded his work with a set of three inkblots presented as slides and printed on cards (Villemor-Amaral \& Primi, 2009).

After the publication of the Rorschach in the Comprehensive System, studies started in different countries to adapt the Comprehensive System to the Zulliger test (Fazendeiro \& Novo, 2012; Mattlar et al., 1990; Zdunic, 1999). In Brazil, the Zulliger had been used collective as well as individually and, as from 2003, there was a progressive increase in the standardization and validation studies to use the Zulliger in the Comprehensive System model, practically all in the adult population. The verification of its validity for use with children is also justified by the reduction of the application and analysis time. It can be used to assess a larger number of individuals in school or institutional contexts, but also as a complementary tool, included in a larger test battery, without putting too much a strain on the child.

A search in the databases of the Virtual Health Library in Psychology (BVS-Psi) and PsycINFO on the studies developed in the childhood population, few studies were found. The studies using the Zulliger with children (Biasi \& Villemor-Amaral, in press; Tavella \& Villemor-Amaral, 2014; Villemor-Amaral \& Quirino, 2013) will be detailed next.

Tavella and Villemor-Amaral (2014) developed a study to verify whether the cognitive and affective indicators on the Zulliger Test which, as a hypothesis, are correlated with creativity, contribute to distinguish children with different creative potentials, identified by the Test of Figural Creativity for Children (TCFI). Ninety children participated, between 
11 and 12 years old, male and female, from public schools in a city in the interior of São Paulo. The Zulliger Test-SC and the TCFI were used. The main variables of the Zulliger that were statistically significant to distinguish the two groups were the number of answers produced (R), which indicates the capacity to be productive from the intellectual viewpoint; the human movement responses (M), which suggest creativity, imagination and empathy; the popular responses $(\mathrm{P})$, which are associated with conventionality and perceptive adequacy; the negative formal quality (FQ-), which refers to errors in the individual's perceptive adjustment. This set of variables demonstrated that the most creative children demonstrated greater production and creation skill on the Zulliger, constituting evidence of validity to use this test in the childhood population.

The goal in the study by Villemor-Amaral and Quirino (2013) was to identify correlations between the Pfister and Zulliger test concerning the integration of Color and Form as predictors of distinguished emotional control and cognitive development levels. Therefore, the tools were administered in 60 participants, being 30 six-year-old children and 30 12-year-old adolescents. Concerning the correlations between the two tools, the authors identified an increase in the responses on the structure formal aspects of the Pfister, accompanied by an increase in pure color $(\mathrm{C})$ answers on the Zulliger, suggesting that, although the group of adolescents presented greater cognitive development than the children, the former's emotional expression tends to be less controlled and in a way unpredictable, being compatible with the instability commonly observed in puberty and adolescence.

Biasi and Villemor-Amaral (in press) sought validity evidence for the use of the Zulliger-SC in children, specifically focusing on the interpersonal relationship indicators. The proposal was to verify whether the interpersonal relationship indicators on the Zulliger-SC managed to distinguish two groups, constituted by the results of a sociogram that appointed popular children and children rejected by their colleagues at a school. Initially, 119 male and female children participated in the research, from the fourth, fifth and sixth year of primary education, from public schools in an interior city in the state of São Paulo. Forty-eight children were selected who obtained a higher score for preferences and rejections and the Zulliger Test was applied individually. In conclusion, the variables related to human movements - Mp and $\mathrm{p}$ and to human contents - $\mathrm{H}$, and the proportion $\mathrm{H}<(\mathrm{H})+\mathrm{Hd}+(\mathrm{Hd})$, was more significant in popular children. In the Rorschach as well as in the Zulliger, these variables identify answers that contain human movements and human content responses, whose quantity and quality predict the interpersonal relationship capacity. In that research, these indicators distinguish the groups in a statistically significant manner, demonstrating that more popular children also have more relational skills than the less popular group. The conclusion was that the Zulliger was able to identify children who performed better or worse on a sociogram, showing evidence of validity for the tool regarding this personality aspect.

The three studies cited focused on specific aspects, such as creativity, cognitive and emotional development and interpersonal relationship of children and adolescents. Based on the promising results cited above, this study intended to proceed with the verification of cognitive and affective variables that, related to development, could reveal different frequencies in the comparison of 6 and 12-year-old children. The study was specifically focused on the variables related to the way the reality is apprehended (W, D, Dd and S, DQ and $\mathrm{Z}$ ); to contact with the reality (FQ+, FQo, FQu and FQ); to changes in perception and thought, such as the special codes DV, DR, INC, FAB, CONTAM, ALOG, PSV, which in general lines represent inappropriate forms of expression or combinations of ideas or images incompatible with the reality. In addition, greater capacity was verified to control the emotions and tensions through the variables $\mathrm{M}, \mathrm{FM}, \mathrm{m}$, C' T, V, Y and, finally, the presence of some more primitive contents, such as Food (Fd), Anatomy (An) and blood (Bl).

\section{Method}

\section{Participants}

To develop this research, a database was used that is being constituted to compose the normative samples of the Zulliger Test for children. The base contained 622 Zulliger Test protocols administered in interior cities in the state of São Paulo. For this study, all protocols of children aged 6 and 12 years old were selected, being in different development stages, favoring the comparison of the results. Thus, 38 protocols of children aged six years old and 65 protocols of participants aged 12 years old were used, totaling 103 protocols.

All children included in the sample had no history of psychiatric or psychological treatment and were regularly enrolled in the expected grade for their age, that is, they had no history of school repetition. To participate, both the person responsible for the child and the child him/herself had to agree to participate in the research voluntarily. The sample consisted of male and female children. Among the participants aged six years, $23(61 \%)$ were female and, among the participants aged 12 years, 35 (54\%) were female.

\section{Instruments}

Zulliger Test. The tool consists of three cards of $24 \times 17$ centimeters, each of them with an inkblot. The application of the Zulliger is divided in two phases. In the first, the individual is expected tell for each of the three cards what the inkblots look like. Then, the person's answers are read and (s)he is expected to say where (s)he saw and what is in the blot that makes it look like the object or element identified. This information permits the coding and appropriate interpretation of the answers, considering quantitative and qualitative aspects. The application time is approximately 30 minutes.

As the literature mentions important changes in the affective and cognitive development in the period between 6 and 12 years, all variables of the Zulliger were addressed. Thus, the indicators related to resources and control, self-perception, affection, interpersonal relationship, processing, mediation and ideas described by Villemor-Amaral and Primi (2009) were assessed and interpreted according to the Comprehensive System (SC). 


\section{Procedure}

Data collection. The protocols stored in the databases were used to compose a normative sample of the Zulliger Test for children and adolescents. The research team, trained for the applications and analyses, elaborated the database, thus guaranteeing the uniformity of the data collection procedures.

The applications happened at public schools located in the interior of the State of São Paulo. In all cases, the Zulliger Test was administered during an individual session that took approximately 30 minutes. The authors of the study classified the answers according to the criteria of the Comprehensive System. Aiming for greater precision of the research data, $25 \%$ of the protocol was drafted for blinded coding by an independent judge, also one of the authors, so that the agreement level of the coding could be verified. Any disagreements were discussed to define the most correct coding, with the help of a third judge.

Data analysis. To seek the evidence of validity on the use of the Zulliger-SC with children, descriptive statistics were used. Next, Student's t-test was used to compare the performance on all variables of the tool according to age, and Cohen's d to check the magnitude of the differences. Parametric and non-parametric analyses were applied to compare the two groups. As both analyses produced the same result, Student's t coefficients were maintained, being a more robust analysis than non-parametric statistics.

\section{Ethical Considerations}

The results presented derive from two pre-existing databases. The studies that permitted the composition of the database complied with all ethical precautions in accordance with CNS resolution 196/96, with approval from the Ethics Committee for Research involving Human Beings at Universidade São Francisco (CAAE n. 0078.0.142.000-07).

\section{Results}

To seek evidence on the validity of the use of the ZulligerSC with children, descriptive statistics were applied, followed by Student's t to compare the performance on all variables of the tool according to age. Table 1 shows the frequency of the coding variables of the answers with significant differences.

Table 1

Comparison of Frequency of Zulliger Coding Variables Between 6 and 12 Years

\begin{tabular}{|c|c|c|c|c|c|c|c|}
\hline Variables & Age & $N$ & $M$ & $S D$ & $t$ & $p$ & $d$ \\
\hline \multirow{2}{*}{ M } & 6 & 38 & 0.42 & 0.76 & \multirow{2}{*}{-2.06} & \multirow{2}{*}{.042} & \multirow{2}{*}{0.42} \\
\hline & 12 & 65 & 0.80 & 0.97 & & & \\
\hline \multirow{2}{*}{$\mathrm{C}^{\prime}$} & 6 & 38 & 0.16 & 0.44 & \multirow{2}{*}{2.23} & \multirow{2}{*}{.032} & \multirow{2}{*}{0.60} \\
\hline & 12 & 65 & 0.00 & 0.00 & & & \\
\hline \multirow{2}{*}{ FY } & 6 & 38 & 0.08 & 0.27 & \multirow{2}{*}{-2.31} & \multirow{2}{*}{.024} & \multirow{2}{*}{0.28} \\
\hline & 12 & 65 & 0.23 & 0.63 & & & \\
\hline \multirow{2}{*}{ FT } & 6 & 38 & 0.00 & 0.00 & \multirow{2}{*}{-2.42} & \multirow{2}{*}{.018} & \multirow{2}{*}{0.38} \\
\hline & 12 & 65 & 0.11 & 0.36 & & & \\
\hline \multirow{2}{*}{ FD } & 6 & 38 & 0.00 & 0.00 & \multirow{2}{*}{-2.05} & \multirow{2}{*}{.045} & \multirow{2}{*}{0.31} \\
\hline & 12 & 65 & 0.06 & 0.24 & & & \\
\hline \multirow{2}{*}{ FQ- } & 6 & 38 & 1.89 & 1.18 & \multirow{2}{*}{2.62} & \multirow{2}{*}{.010} & \multirow{2}{*}{0.53} \\
\hline & 12 & 65 & 1.23 & 1.27 & & & \\
\hline \multirow{2}{*}{$(\mathrm{H})$} & 6 & 38 & 0.53 & 0.73 & \multirow{2}{*}{2.35} & \multirow{2}{*}{.022} & \multirow{2}{*}{0.53} \\
\hline & 12 & 65 & 0.22 & 0.48 & & & \\
\hline \multirow{2}{*}{ Ls } & 6 & 38 & 0.03 & 0.16 & \multirow{2}{*}{-2.22} & \multirow{2}{*}{.029} & \multirow{2}{*}{0.37} \\
\hline & 12 & 65 & 0.14 & 0.35 & & & \\
\hline \multirow{2}{*}{$\mathrm{Fd}$} & 6 & 38 & 0.13 & 0.34 & \multirow{2}{*}{2.02} & 050 & 048 \\
\hline & 12 & 65 & 0.02 & 0.12 & & .050 & 0.48 \\
\hline$\Delta n_{1}$ & 6 & 38 & 0.63 & 0.75 & 204 & 002 & 066 \\
\hline Rinatomity & 12 & 65 & 0.20 & 0.59 & 5.04 & .005 & 0.00 \\
\hline & 6 & 38 & 0.74 & 0.98 & 5 & (2027 & \\
\hline DV & 12 & 65 & 0.32 & 0.62 & 2.35 & .022 & 0.04 \\
\hline
\end{tabular}

Note. $\mathrm{M}=$ human movement; $\mathrm{C}^{\prime}=$ achromatic color; $\mathrm{FY}=$ Diffuse form and Shading; $\mathrm{FT}=$ Texture form and shading; $\mathrm{FD}=$ form dimension; FQ- = uncommon and distorted formal quality; $(\mathrm{H})=$ complete parahuman; $\mathrm{Ls}=$ landscape; Fd = food; Anatomy = anatomy; DV = deviating verbalization. 
In Table 1, it is observed that the six-year-old children had significantly higher averages on the usage frequency of the determinant chromatic color $\left(\mathrm{C}^{\prime}\right)$, of the formal quality minus (FQ-), of parahuman contents $[(\mathrm{H})]$, food $(\mathrm{Fd})$ and anatomy (An) and the special code deviating verbalization (DV), while the 12-year-old participants presented a significant increase in the determinants human movement (M); diffuse shading (FY); texture shading (FT); form dimension (FD) and landscape content (Ls).

In addition, it is important to highlight that it is not enough for the results to reveal statistically significant differences. The effect size of this difference should also be verified. For this end, Cohen (1992) suggested that $d=.20$ is considered of small size, $d=.50$ intermediary and $d=.80$ small. Thus, the variables with a small effect were FY, FT, FD and Ls and with an intermediary effect: M, C', FQ-, (H), Fd, Anatomy and DV. Only the intermediary-effect indicators were discussed, as shown in the Discussion.

In the Zulliger test, data can be inferred about the person through the frequency of certain indicators, but even better when the associations among these indicators are considered, based on formulae, indices and proportions. These variables deriving from calculations that showed significant results can be observed in Table 2 .

Table 2

Comparison of Interpretative Calculations of Zulliger Between 6 and 12 Years of Age

\begin{tabular}{|c|c|c|c|c|c|c|c|}
\hline Variables & Age & $N$ & $M$ & $S D$ & $t$ & $p$ & $d$ \\
\hline \multirow{2}{*}{ S- $\%$} & 6 & 38 & 0.37 & 0.40 & \multirow{2}{*}{2.07} & \multirow{2}{*}{.042} & \multirow{2}{*}{0.46} \\
\hline & 12 & 65 & 0.15 & 0.44 & & & \\
\hline \multirow{2}{*}{ Color with FQ- } & 6 & 38 & 0.37 & 0.54 & \multirow{2}{*}{3.10} & \multirow{2}{*}{.003} & \multirow{2}{*}{0.7} \\
\hline & 12 & 65 & 0.08 & 0.27 & & & \\
\hline \multirow{2}{*}{ Sum of FQ- } & 6 & 38 & 1.26 & 0.98 & \multirow{2}{*}{2.74} & \multirow{2}{*}{.007} & \multirow{2}{*}{0.56} \\
\hline & 12 & 65 & 0.75 & 0.87 & & & \\
\hline \multirow{2}{*}{$\mathrm{An}+\mathrm{Xy}$} & 6 & 38 & 0.42 & 0.55 & \multirow{2}{*}{3.91} & \multirow{2}{*}{$<.001$} & \multirow{2}{*}{3.47} \\
\hline & 12 & 65 & 0.05 & 0.28 & & & \\
\hline \multirow{2}{*}{ Sum of $\mathrm{H}$ content } & 6 & 38 & 0.39 & 0.55 & \multirow{2}{*}{2.25} & \multirow{2}{*}{.029} & \multirow{2}{*}{0.4} \\
\hline & 12 & 65 & 0.17 & 0.38 & & & \\
\hline \multirow{2}{*}{$\mathrm{M}$ with $\mathrm{FQu}$} & 6 & 38 & 0.05 & 0.23 & \multirow{2}{*}{-2.04} & \multirow{2}{*}{.044} & \multirow{2}{*}{0.35} \\
\hline & 12 & 65 & 0.18 & 0.43 & & & \\
\hline \multirow{2}{*}{ WD with FQ- } & 6 & 38 & 1.42 & 1.03 & \multirow{2}{*}{4.55} & \multirow{2}{*}{$<.001$} & \multirow{2}{*}{0.93} \\
\hline & 12 & 65 & 0.60 & 0.79 & & & \\
\hline \multirow{2}{*}{ Y } & 6 & 38 & 0.08 & 0.27 & \multirow{2}{*}{-2.92} & \multirow{2}{*}{.004} & 0.90 \\
\hline & 12 & 65 & 0.38 & 0.76 & & & 0.70 \\
\hline & 6 & 38 & 0.00 & 0.00 & & & \\
\hline 1 & 12 & 65 & 0.11 & 0.36 & -2.42 & .010 & 0.50 \\
\hline U S & 6 & 38 & 1.18 & 1.23 & 274 & 007 & 055 \\
\hline visuinto & 12 & 65 & 0.57 & 1.02 & 2.14 & .001 & 0.55 \\
\hline $\mathrm{Y} \wedge 0^{\circ}$ & 6 & 38 & 0.69 & 0.16 & 252 & 001 & 077 \\
\hline$\Lambda A \% 0$ & 12 & 65 & 0.80 & 0.15 & (-5.5) & .001 & 0.12 \\
\hline WDA 0 & 6 & 38 & 0.71 & 0.18 & 405 & 01 & 006 \\
\hline WDA\% & 12 & 65 & 0.86 & 0.14 & -4.85 & .001 & 0.90 \\
\hline $\mathrm{Y}$ & 6 & 38 & 0.38 & 0.18 & > & 048 & 047 \\
\hline$\Lambda+\%$ & 12 & 65 & 0.47 & 0.23 & -2.00 & .040 & 0.42 \\
\hline $\mathrm{Y} 0$ & 6 & 38 & 0.29 & 0.15 & 201 & 1 & 090 \\
\hline & 12 & 65 & 0.17 & 0.15 & 5.71 & .001 & 0.00 \\
\hline
\end{tabular}

Note. S- $\%=$ sum of answers with blank space and with uncommon and distorted formal quality; Color with FQ- = chromatic color response with uncommon and distorted formal quality; $\mathrm{An}+\mathrm{Xy}=$ sum of anatomy response and X ray; Sum of $\mathrm{H}$ content $=$ sum of complete human content; $\mathrm{M}$ with $\mathrm{FQu}=$ total human movement response with uncommon and distorted formal quality; WD with FQ- = total global and usual response with uncommon and distorted formal quality; $\mathrm{Y}=; \mathrm{T}=$ texture response without form; WSum6 = weighted sum of special responses; $\mathrm{XA} \%=$ percentage of response sum with elaborated or super-elaborated, ordinary and uncommon formal quality; WDA $\%=$ sum of XA $\%$ with global and usual response; $\mathrm{X}+\%=$ percentage of sum of response with elaborated or super-elaborated and ordinary formal quality; X- $\%$ $=$ percentage of sum of response with uncommon and distorted formal quality. 
In Table 2, it is observed that the six-year-old children obtained an increase by S- \% (sum of locations that included blank space, associated with formal quality minus), Color with FQ-, Sum of FQ-, An+Xy, Sum of content H, WD with FQ- (sum of $\mathrm{W}$ and D location answers, associated with formal quality minus), WSum6 (sum of weighted values of special codes) and $\mathrm{X}-\%$ (formal quality minus). The 12-yearold children presented an increase in the variables $M$ with $\mathrm{FQu}, \mathrm{Y}, \mathrm{T}, \mathrm{XA} \%, \mathrm{WDA} \%$ and $\mathrm{X}+\%$. Cohen's $d$ coefficients indicated that the variables $\mathrm{M}$ with $\mathrm{FQu}$ and $\mathrm{T}$ presented a small effect size and, therefore, the choice was made not to discuss them in this research.

\section{Discussion}

To verify to what extent the Zulliger-SC test permits identifying the cognitive and emotional differences expected according to the child's development phases, the data obtained through the application of the Zulliger to six and 12-year-old children were compared. Among the variables with significant differences observed in Table 1, the discussion can start with the determinant $\mathrm{M}$, which appeared higher in the 12-year-old group. According to Weiner (2000), this determinant indicates the presence of projective loading in the response, representing psychological activities that involve the evocation of mental registers of the experiences and their attribution to the stimulated area. Hermann Rorschach himself already considered $\mathrm{M}$ a sign of greater maturity and intelligence. It should be reminded that the determinant $\mathrm{M}$ was also higher in the group of creative adolescents in the study by Tavella and Villemor-Amaral (2014), and ranked as one of the most popular in the research by Biasi and Villemor-Amaral (in press). On the other hand, it should be highlighted that the increase in $\mathrm{M}$ for the 12-year-old children in this sample is associated with the increase in FQu, as can be observed in Table 2, suggesting a more personal form of using the ideas without necessarily indicating disorder. This more peculiar mode of observing the facts in adolescence is typical of the need to grow and constitute one's own identity, which may be associated with frequent conflicts in this development period, as shown further ahead.

The variable C' was more frequent in the six-year-old group. This variable indicates an involuntary and automatic process of internalization of feelings that may increase an internal unease due to the brake on emotional expression, being hardly effective from the adaptation viewpoint (Weiner, 2000). Although an isolated piece of information does not permit many inferences (Exner \& Sendín, 1999), everything depending on the context, it is verified that, somehow, the younger children are more prone to this type of emotional response, which is less mature.

The Formal Quality (FQ) indicators provide information on the degree of perceptive adequacy between the stimulus of the inkblot and the subject's mnemonic associations. FQsuggests a distorted or hardly effective perception of the reality (Exner \& Sendín, 1999). In a way, younger children are expected to tend to provide more FQ- answers than 12 -year olds. Similar results were obtained in the study by Resende et al. (2012), using the Rorschach-SC in children.
According to Piaget (1978), around the age of six years, for example, children have more magical and egocentric thinking, marked by the child's own and not socially shared logic. In this phase, children have not appropriated themselves of the more socialized mode of thinking yet, which is expected to have occurred by the age of 12 years, when the child is already in the so-called formal operative period.

Concerning Zulliger's content variables, it is interesting to note that six-year-old children presented a significant increase with intermediary effect size in $(\mathrm{H}), \mathrm{Fd}$ and An. The first indicator supposes that the child has an imaginative and fanciful conception of the human relations. The second expresses more dependent behavior and a certain expectation that others will satisfy their needs, in line with Piaget's proposals (1978), while the responses by An suggest concern with the body. This combination of phenomena is coherent with what is expected for six-year-old children, who naturally have a more immature view of themselves and the other, present magical thinking in which fantasy prevails and are hardly able to take on the correct mindset, granting the body a more preponderant presence in the infant mind (Marty, 1998).

Finally, the increase in DV was observed in the six-yearold children. DV answers may imply the distorted use of verbalizations, reducing the clarity of communication (Exner \& Sendín, 1999). Six-year olds are expected to have a more limited vocabulary than 12-year olds, as the vocabulary tends to grow considerably in the course of the education process. This can lead to the mistaken use of words and concepts, a limitation that is characteristic of development, which would not constitute a pathological change of thought. At the age of 12 years, language gains a fundamental role, serving as conceptual support to be able to develop more abstract thinking, typical of the formal operative stage. Thus, the language can get more appropriate and precise than that of younger children.

S-\%, which indicates the extent to which emotional interferences can distort the subject's perceptive processes (Exner \& Sendín, 1999), was another more frequent variable among the younger children in this study. Its increase in sixyear olds can derive from the emotional immaturity that makes a negative feeling compromisse an objective understanding of the facts. This result is associated with the concomitant sum of color answers with FQ-, which is also higher in the group of six-year-old children, and may suggest the child's failure to control emotional impulse, associated with the distortion of reality or with a trend to draw precipitated conclusions (Villemor-Amaral \& Primi, 2009).

As mentioned, the increase in An, now in combination with x-ray answers (Xy), indicates concerns with the body, which may point towards changes in the self-image and the attitudes towards oneself (Exner \& Sendín, 1999), mainly for adults. These indicators together reinforce the hypothesis of a more primitive functioning for six-year-old children, which may be related to the immaturity characteristic of who has not properly imagined the mental and affective difficulties yet, maintaining them at a more bodily level, as mentioned.

The increase in the sum of $\mathrm{H}$ content should be considered in relation to the type of $\mathrm{H}$ content. In Table 1, it 
was observed that the six-year olds presented an increase in $(\mathrm{H})$, suggesting distancing from the reality, indicating greater investment in fantasy when coping with the perceptions of oneself and the other (Exner \& Sendín, 1999). This idea seems to strengthen the characteristics mentioned earlier that children in the preoperative period tend to focus more on self-oriented functioning, with a still limited understanding of the surrounding world. In the study by Biasi and VillemorAmaral (in press), the group of children considered unpopular also presented increased $(\mathrm{H}),(\mathrm{Hd})$ and $\mathrm{Hd}$ answers.

Associated with a significantly higher FQ-, WD in sixyear olds strengthens the increase in distorted perceptions when compared to 12-year-old adolescents, even under the most common circumstances. WSum6 results from the weighted sum of the critical Special Codes and, therefore, its increase should be considered in function of which of the codes this increase occurs in. In this study, returning to Table 1 , it is verified that this increase among the younger children is due to the rise in DV, which also, as discussed, may simply identify language errors characteristic of children who are gaining literacy.

The increase in $\mathrm{XA} \%, \mathrm{WDA} \%$ and $\mathrm{X}+\%$ in older when compared to younger children suggests a more appropriate and realistic perception of the context among the older children, as a natural consequence of development. $\mathrm{O}$ $\mathrm{XA} \%$ refers to the sum of formal quality answers that are considered appropriate answers to the contours of the inkblot, independently of being common or not (FQo + $\mathrm{FQu}+\mathrm{FQ}+$ ), and $\mathrm{WDA} \%$ refers to the appropriateness of the formal quality of the answers in $\mathrm{W}$ and $\mathrm{D}$, excluding $\mathrm{Dd}$ (Nascimento, 2010), while $\mathrm{X}+\%$ superior to the expected average suggests hyperconventionality, indicating submission to external standards (Exner \& Sendín, 1999). Thus, XA\%, $\mathrm{WDA} \%$ and $\mathrm{X}+\%$ answers provide information on the perceptive appropriateness of reality (Nascimento, 2010). The fact that these variables are increased in the 12-year-old group suggests that the Zulliger reflects the extent to which the perceived external reality is balanced with development, according to Piaget. In other words, the young people in this research assimilate and accommodate a larger amount of cultural information, adapting to the social conventions. Similar data were found in Rorschach-SC studies involving children (Resende et al., 2012).

The $\mathrm{Y}$ answers were also more frequent in the adolescent group. These answers emerge in response to external situations that cause tension or discomfort, suggesting increased suffering and the presence of paralyzing emotions (Exner \& Sendín, 1999). Their greater appearance at the age of 12 than at the age of six years strengthens the idea that the onset of adolescence is naturally full of conflicts that cause anguish and contributes to demonstrate that the Zulliger permits the expression of these developmental characteristics.

The set of variables highlighted in this study made it possible to distinguish emotional, social and cognitive aspects of childhood development typical of the different age ranges, contributing to evidences of validity of the ZulligerSC (Villemor-Amaral \& Primi, 2009) when used with children and young adolescents. These findings follow the same sense of studies using the Rorschach for children, in line with the research by Nascimento et al. (2009), Resende et al. (2012), Ribeiro et al. (2011), Semer (2008) and Viglione (1999) on the Rorschach-SC and indirectly with the findings by Fernandes (2010), Hisatugo and Custódio (2013), Jacquemin (2012) and Raspantini (2010), which indicated the possible use of the inkblots method to assess children. Hence, like in the Rorschach, it is considered that the Zulliger permits an appropriate assessment of the children and can be used mainly in situations in which a larger group of individuals is assessed.

The Zulliger test permitted distinguishing two groups of distinct age ranges, contributing to the initiative to introduce, in Brazil, the use of the Zulliger in the Comprehensive System to assess children. The number of participants in this research can be considered consistent for studies using expressive methods, but restricted for the establishment of normative standards, also keeping in mind that, although the sample consisted of individuals from different cities in the interior of São Paulo, it was limited to a small part of the Brazilian territory.

Despite the positive results presented, it is fundamental to develop further research to seek further evidence on the validity of the Zulliger Comprehensive System for use with different age ranges. One important suggestion that would significantly contribute to understand the range and limits of the Zulliger as a psychological assessment tool is the development of not only cross-sectional studies like the study presented in this paper, but also longitudinal studies.

\section{References}

Biasi, F. C., \& Villemor-Amaral, A. E. (2016). Evidências de validade do Zulliger-SC para avaliação do relacionamento interpessoal de crianças [Zulliger - SC validity of evidence to evaluate the interpersonal relationship of children]. Psico, 47(1), 13-23.

Cohen, J. (1992). A power primer. Psychological Bulletin, $112(1), 155-159$.

Exner, J. E., Jr., \& Sendín, C. (1999). Manual de interpretação do Rorschach para o Sistema Compreensivo [The Rorschach: A Comprehensive System: Interpretation] (A. C. P. Silva Neto, Trans.). São Paulo, SP: Casa do Psicólogo.

Fazendeiro, H. M. M., \& Novo, R. J. F. (2012). Versão coletiva do teste de Zulliger segundo o Sistema Compreensivo do Rorschach [Zulliger group test according to the Rorschach Comprehensive System]. Avaliação Psicológica, 11(3), 407422.

Fernandes, S. (2010). Normas do Rorschach em crianças de seis a oito anos [Norms for the Rorschach in six to eight-year-old children] (Master's thesis). Retrieved from http://www.teses.usp.br/teses/disponiveis/59/59137/tde23102013-150520/en.php

Hisatugo, C. L. C., \& Custódio, E. M. (2013). Avaliação psicológica e da personalidade e o estudo normativo do Rorschach para o uso em crianças brasileiras [Psychological assessment and personality and study 
of regulatory Rorschach for use in Brazilian children]. Psicólogo inFormação, 17(17), 79-86. doi:10.15603/21760969/pi.v17n17p79-86

Jacquemin, R. C. P. (2012). Padrões normativos do psicodiagnóstico de Rorschach em adolescentes de 12 a 14 anos [Normative data for the Rorschach psychodiagnostic test in adolescents aged 12-14 years] (Master's thesis). Retrieved from http://www.teses.usp.br/teses/ disponiveis/59/59137/tde-10072013-161031/pt-br.php

Marty, P. (1998). Mentalização e psicossomática [Mentoring and psychosomatic] (A. E. V. A. Güntert, Trans.). São Paulo, SP: Casa do Psicólogo.

Mattlar, C.-E., Sandahl, C., Lindberg, S., Lehtinen, V., Carlsson, A., Vesala, P., \& Mahmood, Z. (1990). Methodological issues associated with the application of the comprehensive system when analysing the Zulliger, and the structural resemblance between the Zulliger and the Rorschach. British Journal of Projective Psychology, 35(2), 17-27.

Nascimento, R., Pedroso, J. S., \& Souza, A. M. (2009). Método de Rorschach na avaliação psicológica em crianças: Uma revisão de literatura [Rorschach in children psychological assessment: A literature revision]. Psico-USF, 14(2), 193200. doi:10.1590/S1413-82712009000200008

Nascimento, R. S. G. F. (2010). Sistema Compreensivo do Rorschach: Teoria, pesquisa e normas para a população brasileira [Comprehensive System of Rorschach: Theory, research and standards for the Brazilian population]. São Paulo, SP: Casa do Psicólogo.

Nunes, M. L. T., Teixeira, R. P., \& Deakin, E. K. (2010). Técnicas projetivas e avaliação de psicoterapia psicanalítica com crianças [Projective techniques and evaluation of psychoanalytic psychotherapy with children]. In M. L. T. Nunes (Org.), Técnicas projetivas com crianças [Projective techniques with children] (pp. 145-170). São Paulo, SP: Casa do Psicólogo.

Piaget, J. (1978). A epistemologia genética / Sabedoria e ilusões da filosofia / Problemas de psicologia genética [The genetic epistemology /Wisdom and illusions of philosophy / psychology genetic problems] (N. C. Caixeiro, Trans.). São Paulo, SP: Abril Cultural.

Raspantini, R. L. (2010). O psicodiagnóstico de Rorschach em crianças de 9 a 11 anos: Um estudo normativo [Rorschach's psychodiagnostic test in 9 to 11-yearold children: A normative study] (Master's thesis). Retrieved from http://www.ffclrp.usp.br/imagens_ defesas/01_02_2011_08_50_55_61.pdf

Resende, A. C., Carvalho, T. C. R., \& Martins, W. (2012). Desempenho médio de crianças e adolescentes no método de Rorschach Sistema Compreensivo [Average performance of children and adolescents in the Rorschach Comprehensive System]. Avaliação Psicológica, 11(3), 375-394.

Ribeiro, R. K. S. M., Semer, N. L., \& Yazigi, L. (2011). Rorschach Comprehensive System norms in Brazilian children from public and private schools. Psicologia: Reflexão e Crítica, 24(4), 671-684. doi:10.1590/S010279722011000400007
Semer, N. L. (2008). A utilização do Rorschach em crianças e adolescentes [The use of Rorschach in children and adolescentes]. In A. E. Villemor-Amaral \& B. S. G. Werlang (Orgs.), Atualizações em métodos projetivos para avaliação psicológica [Updates on projective methods for psychological evaluation] (pp. 95-106). São Paulo, SP: Casa do Psicólogo.

Tavella, R. R., \& Villemor-Amaral, A. E. (2014). O teste de Zulliger-SC: Avaliação da criatividade em crianças [The Zulliger-SC test: Assessment of children's creativity]. Estudos de Psicologia (Campinas), 31(4), 489-497. doi:10.1590/0103-166X2014000400003

Viglione, D. J. (1999). A review of recent research addressing the utility of the Rorschach. Psychological Assessment, 11(3), 251-265. doi:10.1037/1040-3590.11.3.251

Villemor-Amaral, A. E., \& Primi, R. (2009). Teste de Zulliger no Sistema Compreensivo ZSC: Forma individual [The Zulliger test the Comprehensive System: individual form]. São Paulo, SP: Casa do Psicólogo.

Villemor-Amaral, A. E., \& Quirino, G. S. (2013). Estudo comparativo entre indicadores afetivos das técnicas de Pfister e Zulliger [Comparative study between the affective indicators of Zulliger and Pfister tests]. Avaliação Psicológica, 12(1), 1-7.

Weiner, I. B. (2000). Princípios de interpretação do Rorschach [Principle of Rorschach interpretation] (M. C. V. M. Silva, Trans.). São Paulo, SP: Casa do Psicólogo.

Zdunic, A. L. (1999). El teste de Zulliger en la evaluación de personal: Aportes del Sistema Compreensivo de Exner. Buenos Aires, Argentina: Paidós.

Anna Elisa de Villemor-Amaral is a Professor of the Universidade São Francisco.

Pâmela Malio Pardini Pavan is a M.S. candidate of the Graduate Program in Psychology of the Universidade São Francisco

Raquel Rossi Tavella is a Professor of the Centro Universitário Nossa Senhora do Patrocínio.

Lucila Moraes Cardoso is a Professor of the Universidade Estadual do Ceará.

Fabiola Cristina Biasi is a Professor of the Universidade São Francisco.

Received: Apr. 8, 2015

1st Revision: Aug. 25, 2015

Approved: Sep. 18, 2015

How to cite this article:

Villemor-Amaral, A. E., Pavan, P. M. P, Tavella, R. R., Cardoso, L. M., \& Biasi, F. C. (2016). Validity evidence of the Z-Test-SC for use with children. Paidéia (Ribeirão Preto), 26(64), 199-206. doi:10.1590/198243272664201607 